\title{
A INCIDÊNCIA DAS CONTRIBUIÇÕES PREVIDENCIÁRIAS SOBRE A PRODUÇÃO RURAL E SEUS ASPECTOS CONTROVERTIDOS
}

\section{THE SOCIAL SECURITY CONTRIBUTIONS INCIDENCE ON RURAL PRODUCTION AND ITS CONTROVERSIAL ASPECTS}

\author{
André Mendes Moreira \\ Universidade Federal de Minas Gerais - UFMG - (Belo Horizonte, Minas Gerais, Brasil) \\ Luiz Felipe Mendes Álvares da Silva Campos \\ Universidade Federal de Minas Gerais - UFMG - (Belo Horizonte, Minas Gerais, Brasil)
}

Recebimento: 12 mar. 2019

Aceitação: 8 abr. 2019

\begin{abstract}
Como citar este artigo / How to cite this article (informe a data atual de acesso / inform the current date of access):
MOREIRA, André Mendes; CAMPOS, Luiz Felipe Mendes Álvares da Silva. A incidência das contribuições previdenciárias sobre a produção rural e seus aspectos controvertidos. Revista da Faculdade de Direito UFPR, Curitiba, PR, Brasil, v. 64, n. 1, p. 187-214, jan./abr. 2019. ISSN 2236-7284. Disponível em: <https://revistas.ufpr.br/direito/article/view/65407>. Acesso $\quad$ em: $30 \quad$ abr. $2019 . \quad$ DOI:
\end{abstract} http://dx.doi.org/10.5380/rfdufpr.v64i1.65407.

\section{RESUMO}

O presente estudo analisa diversas questões relativas às contribuições sociais previdenciárias incidentes sobre a produção rural. Inicialmente, investiga-se o status legal dos sujeitos passivos da contribuição social previdenciária, por meio da análise da redação originária conferida aos dispositivos legais pertinentes e suas subsequentes alterações, até a composição da legislação atualmente em vigor. Em seguida, são discutidas as questões constitucionais atuais da matéria pertinente, partindo-se do que já foi decidido pela Suprema Corte brasileira no julgamento do Recurso Extraordinário (RE) n $n^{\circ} 718.874 / R S$, até as temáticas que serão decididas nos próximos anos e que se relacionam ao segurado especial pessoa física, à exigência controvertida da Contribuição para o Financiamento da Seguridade Social (Cofins) concomitantemente com a contribuição do Fundo de Assistência ao Trabalhador Rural (Funrural) em face das pessoas jurídicas e ao alcance da imunidade de receitas de exportação, especificamente no caso das exportações indiretas feitas por empresas comerciais exportadoras. Por fim, são examinados os temas julgados recentemente pelo Conselho Administrativo de Recursos Fiscais (Carf), que poderão ser submetidos em breve à apreciação do Poder Judiciário, bem como questão sobre a qual potencialmente advirá decisão do referido órgão paritário integrante do Ministério da Fazenda.

\section{PALAVRAS-CHAVE}

Contribuição previdenciária. Funrural. Jurisprudência. Produção rural. Receitas.

\begin{abstract}
This study examines issues regarding social security contribution on rural production. Initially, the social security contribution on rural production taxable person legal status is examined by analysing the original text of the applicable legal devices and its amendments through time. Subsequently, it addresses to the current constitutional issues concerning the matter; starting with the Brazilian Supreme Court decision provided in Extraordinary Appeal No. 718.874/RS, up to themes that will be
\end{abstract}


decided in the coming years, regarding: The special insured person, the controversial tax requirement of legal persons that have the same constitutional foundation and the export revenue immunity in indirect operations carried out by export trading companies. Finally, it analyses correlated themes regarding recent cases decided by the Administrative Tax Appeals Board, which may be submitted soon to the Judiciary Branch, and a specific legal point that also may be submitted to the same administrative board linked to the Brazilian Ministry of Finance.

\section{KEYWORDS}

Social security contribution. Funrural. Jurisprudence. Rural production. Revenue.

\section{INTRODUÇÃO: A RELEVÂNCIA DO SETOR DO AGRONEGÓCIO PARA O BRASIL}

O setor do agronegócio no Brasil tem participação em aproximadamente 25\% do produto interno bruto (PIB) nacional, o que torna inegável sua importância para a economia pátria e impõe a necessidade de atento exame sobre a repercussão de suas atividades. De acordo com dados do Instituto Brasileiro de Geografia e Estatística (IBGE) e do Centro de Estudos Avançados em Economia Aplicada da Universidade de São Paulo (Cepea/USP), esse setor gerou para o PIB o correspondente a R\$ 1,4 trilhão no ano de 2016. Por sua vez, segundo informa a Reuters, a contribuição do setor em 2017 alcançou 23,5\% do PIB brasileiro ${ }^{1}$. Ao realizar censo agropecuário, em 2017, o IBGE registrou, em resultados preliminares, a existência de aproximadamente 5,07 milhões de propriedades rurais no Brasil, correspondente à área de mais de 350 milhões de hectares.

Além disso, é imprescindível salientar que o agronegócio é responsável por quase metade das exportações totais do País; em 2017 - conforme o Cepea/USP a partir de dados fornecidos pelo Ministério da Indústria, Comércio Exterior e Serviços (MDIC) ${ }^{2}$-, a participação do segmento foi de 44\% nas exportações, contribuindo para assegurar o superávite de aproximadamente US\$ 66 bilhões da balança comercial brasileira no período. Em 2018, o agronegócio brasileiro atingiu recorde nominal de US\$ 101,7 bilhões, que traduz crescimento de 5,9\% em relação a $2017^{3}$.

Ainda sobre dados relativos à exportação, destaca-se que o Brasil: é o líder mundial em exportação de soja e o segundo maior produtor do grãos no planeta - segundo relatório de estimativa de oferta e demanda mundial para fevereiro de 2019 do United States Department of Agriculture (USDA) a produção brasileira na safra 2018/2019 deverá ser de 117 milhões de toneladas ${ }^{4}$, valor reproduzido pela Conab na análise mensal de fevereiro de $2019^{5}$-; encontra-se na segunda posição no ranking da exportação mundial de milho e é o terceiro maior exportador de algodão.

\footnotetext{
${ }^{1}$ Cf. disponível em: https://bit.ly/2IFZWEu. Acesso em: 28 dez. 2018.

${ }^{2}$ Cf. disponível em: https://bit.ly/2Zxox3B. Acesso em: 28 dez. 2018.

${ }^{3}$ Cf. disponível em: https://bit.ly/2IK5pKD. Acesso em: 18 jan. 2019.

${ }^{4}$ Cf. disponível em: https://bit.ly/2XDzkY3. Acesso em: 20 fev. 2019.

${ }^{5}$ Cf. disponível em: https://bit.ly/2W5B9fY. Acesso em: 20 fev. 2019.
} 
Por último, mas não menos importante, é interessante notar que o segmento em foco gera quase 20 milhões de empregos no Brasil, porém somente quatro milhões deles estão situados no meio rural. De início, este fato incita questionar se há razão para tributação diferenciada com o fim de custear a seguridade social, no que concerne aos trabalhadores rurais. Essa diferenciação tributária tem raízes históricas no Brasil e remonta à inauguração da proteção previdenciária do trabalhador rural com a edição da Lei Complementar n 11/1971, que criou o Programa de Assistência ao Trabalhador Rural (Prorural), custeado pelo Fundo de Assistência ao Trabalhador Rural (Funrural), que, por sua vez, foi criado pela Lei n 4.214/1963 (Estatuto do Trabalhador Rural). Diante da notória relevância que o setor tem para o desenvolvimento social e econômico do País e ante as mais variadas repercussões nos subsistemas do Direito, impõe-se um exame atento acerca da temática.

O panorama jurídico criado pelos mencionados dispositivos foi intensamente alterado com a promulgação da Constituição da República Federativa do Brasil de 1988, que inovou ao dispor sobre o sistema da seguridade social. É exatamente neste cenário - levando-se em conta as modificações constitucionais ocorridas - que o presente trabalho se desenvolverá.

Como se sabe, o ordenamento constitucional brasileiro originário estipulou o financiamento da seguridade social com base em diversas fontes, dentre as quais estão as contribuições sociais. Dentre elas, ressaltamos - para o estudo aqui proposto - as previstas no art. 195, incisos I e II e parágrafo $8^{\circ}$, devidas: pelo empregador, incidente sobre a folha de salários, lucro e faturamento; pelos trabalhadores; e pelos produtores rurais em regime de economia familiar, incidente sobre o resultado da comercialização da produção. Na esfera infraconstitucional, a regulação se deu mediante a Lei Orgânica da Seguridade Social - Lei nº 8.212/1991 -, que reprisou as bases imponíveis tributárias em atenção à hierarquia normativa.

Com a promulgação da Emenda Constitucional (EC) $\mathrm{n}^{0}$ 20, de 1998, os dispositivos constitucionais atinentes às contribuições sociais previdenciárias foram alterados. Por outro lado, as maiores mudanças para os produtores rurais ocorreram no âmbito da legislação federal. É que, nos anos de 1992, 1994 e 2001, o Congresso Nacional editou, respectivamente, as Leis $\mathrm{n}^{\circ} 8.540, \mathrm{n}^{\circ} 8.870$ e ${ }^{0}$ 10.256, que inauguraram a oneração tributária da produção rural das pessoas físicas e jurídicas, ao delimitarem a incidência da contribuição previdenciária sobre a receita bruta proveniente da comercialização da produção rural. Assim, houve deslocamento da oneração tributária, ante a substituição da exação tributária incidente sobre a folha de salários.

Pode-se dizer que a substituição da base imponível para a produção rural conforme feita era, à época, benéfica ao empregador rural - pessoa física ou pessoa jurídica -, devido ao elevado número de mão de obra empregada no meio rural, o que, por óbvio, implica maiores custos baseados na folha 
de salários. Contudo, com os avanços tecnológicos e a crescente mecanização dos trabalhos no campo, diversos segmentos do agronegócio não se beneficiam dessa tributação, na medida em que a redução do número de empregados e, consequentemente, diminuição da monta da folha de salários, torna a incidência tributária sobre esta última menos gravosa financeiramente.

Delineia-se, assim, o pano de fundo jurídico-tributário das contribuições previdenciárias incidentes sobre a produção rural, que oneram a produção rural brasileira. À vista disso e com fins de melhor tratarmos a matéria, o presente trabalho dividir-se-á nas seguintes partes: (i) análise sobre o status legal da contribuição previdenciária - denominada por convenção Funrural - com a delimitação das regras pertinentes aos sujeitos passivos da exação; (ii) verificação dos temas constitucionais afetados pelo Supremo Tribunal Federal (STF) que tem repercussão direta no Funrural; (iii) apuração das questões atualmente controvertidas no Conselho Administrativo de Recurso Fiscais referentes àquelas contribuições sociais previdenciárias.

\section{STATUS LEGAL DA QUESTÃO DO FUNRURAL: DA INCIDÊNCIA DA CONTRIBUIÇÃO PREVIDENCIÁRIA SOBRE REMUNERAÇÕES PAGAS A PESSOAS FÍSICAS À CONTRIBUIÇÃO INCIDENTE SOBRE RECEITA BRUTA}

Consoante ressaltado, o Funrural foi criado pela já revogada Lei no 4.214/1963, para custear a assistência médico-social daqueles trabalhadores e seus dependentes. Nesse período, estipulou-se que a contribuição devida pelo produtor rural para composição do fundo seria calculada pelo valor comercial dos produtos rurais. Posteriormente, os recursos do Funrural foram destinados ao Prorural, instituído pela Lei Complementar nº 11/1971.

Ante a unificação da previdência social e a instituição da Seguridade Social promovida pela Constituição de 1988, o legislador constituinte positivou, no art. 195, a matriz constitucional das contribuições em estudo, que possuíam distintas peculiaridades relacionadas ao sujeito passivo. É que, caso o sujeito passivo fosse empregador, o tributo originariamente incidiria sobre a folha de salários, ao passo que, se se tratasse de produtor rural pessoa natural em regime de economia familiar, sem empregados, a base imponível seria o resultado da comercialização da sua produção, consoante dispõe o art. 195, parágrafo 8º da Constituição de 1988. Destaque-se, por oportuno, que este último preceito constitucional criou uma exceção, cuja razão de ser será explicitada alhures.

Posteriormente, em 1998, com a promulgação da EC $\mathrm{n}^{0}$ 20, foi adicionada a receita como nova base de cálculo para contribuições sociais, alteração esta que, como será visto, teve reflexos diretos na contribuição ao Funrural. Diante desse panorama constitucional, a fim de tratar da matéria, 
o legislador federal editou a Lei Orgânica da Seguridade Social (Lei nº 8.212/1991), modificada em diversas ocasiões até alcançar a atual redação.

Relevando-se parte da evolução histórica da legislação pertinente à matéria para darmos maior enfoque nas disposições legais vigentes a que se sujeitam os contribuintes, veremos a seguir as realidades jurídico-tributárias dos produtores rurais separados em quatro espécies, de acordo com a legislação federal: (1) segurado especial; (2) empregador rural pessoa física; (3) empregador rural pessoa jurídica; e (4) agroindústria.

\subsection{O SEGURADO ESPECIAL}

Essa espécie de sujeito passivo corresponde à pessoa física produtora rural que atue em regime de economia familiar, isto é, desenvolva a atividade em caráter indispensável à subsistência própria e ao desenvolvimento socioeconômico do núcleo familiar, sem utilização de empregados permanentes, consoante definido no art. 12, inciso VII e parágrafo $1^{\circ}$, da Lei nº 8.212/1991.

Cuida-se daquele contribuinte que recebeu tratamento tributário diferenciado pelo texto constitucional (art. 195, parágrafo $8^{\circ}$ ), com incidência da contribuição sobre o resultado da comercialização da produção rural. Esse tratamento é plenamente justificável, na medida em que é inviável a incidência da exação sobre a folha de salários, dada a inexistência de empregados que, inclusive, caracteriza o sujeito passivo em questão.

Atualmente, averigua-se que o produtor rural pessoa física caracterizado como segurado especial recolhe a contribuição previdenciária destinada ao custeio da seguridade social por meio da aplicação da alíquota de 1,2\% sobre a receita bruta decorrente da comercialização da sua produção, nos ditames do art. 25, inciso I, da Lei nº 8.212/1991.

\subsection{O EMPREGADOR RURAL PESSOA FÍSICA}

Trata-se do produtor rural pessoa física que desempenha sua atividade por intermédio da contratação de empregados. Nesse sentido, as obrigações tributárias em relação à seguridade social dão-se tanto como contribuinte individual, quanto como empregador, sendo que cumpre dar enfoque a esta última sujeição, para o que se propõe no presente artigo.

A partir da leitura dos dispositivos infraconstitucionais vigentes, conclui-se que o empregador rural em exame pode optar por recolher a contribuição previdenciária sobre a folha de salários, ou sobre a receita bruta proveniente da comercialização da sua produção. Essa opção pelo modo de contribuição foi incluída recentemente pela Lei nº 13.606/2018 e é exercida anualmente de 
maneira irretratável, operando-se por meio do pagamento da exação incidente sobre a folha de salários. Desse modo, nota-se que atualmente a regra geral prevista é a da tributação com base na receita bruta decorrente da comercialização da produção, devendo o sujeito passivo, caso queira usufruir da incidência sobre a folha de pagamentos, realizar manifestação expressa via quitação do tributo calculado sobre essa última base imponível - folha de salários.

Na hipótese de incidência tributária sobre a folha de salários, o tributo devido será calculado à alíquota de 20\% aplicada sobre o total das remunerações pagas, devidas, ou creditadas, além da nominada contribuição destinada aos Riscos Ambientais do Trabalho (RAT), que possui alíquotas variáveis em conformidade com o risco da atividade. Alternativamente à essas exações, no caso da tributação prevista na regra geral vigente, o empregador rural pessoa física contribuirá para a seguridade social com $1,2 \%$ da receita bruta oriunda da comercialização da produção rural, igualmente ao segurado especial.

É interessante notar que a alíquota da contribuição do empregador rural era de $2 \%$ até o advento da Medida Provisória $n^{0}$ 793/2017, que promoveu redução para 1,2\% para ajustar a carga tributária do produtor rural pessoa física. É o que se vê na Exposição de Motivos nº 00095/2017 MF:

\begin{abstract}
8. A outra proposta se refere à alteração da alíquota da contribuição do empregador rural incidente sobre a receita bruta proveniente da comercialização, que passa de $2 \%$ (dois por cento) para 1,2\% (um inteiro e dois décimos por cento). A redução da alíquota tem como objetivo ajustar a carga tributária do produtor rural pessoa física tendo em vista a crescente mecanização da produção com a consequente redução de empregados e da folha salarial para muitos produtores, o que faz com que essa contribuição, na alíquota atual, represente peso muito grande no custo de produção desses produtores. (BRASIL, 2017).
\end{abstract}

Em que pese o encerramento do prazo de vigência da referida medida provisória, certo é que a alíquota de 1,2\% foi mantida pela Lei $\mathrm{n}^{\circ}$ 13.606/2018, em acertado ajuste da carga tributária dos produtores rurais pessoas físicas.

Demais disso, outro ponto merece destaque, dadas as amplas discussões na doutrina. Como se percebe, foi positivado na Constituição de 1988 que apenas o produtor rural pessoa física em regime de economia familiar poderia se valer da tributação com base no resultado da comercialização da produção, tratando-se de verdadeira exceção à regra. Todavia, essa base de cálculo foi estendida às pessoas físicas que desempenham atividade de produção rural com empregados, de maneira imprópria para grande parte da doutrina. Apesar disso, adiantando o que será tratado no próximo tópico, cumpre dizer que o STF convalidou a incidência da contribuição previdenciária sobre a receita bruta decorrente da comercialização da produção, no caso do empregador rural pessoa física. Assim, de acordo com pronunciamento do STF, a conjuntura legal atual está em consonância com os mandamentos constitucionais. 


\subsection{O EMPREGADOR RURAL PESSOA JURÍDICA}

Cuida-se da espécie de produtor rural constituído como pessoa jurídica - firma individual ou empresário individual, nos termos do art. 931 do Código Civil -, cuja atividade consiste em produzir e vender produtos rurais sem processos de beneficiamento ou industrialização daquela produção, mediante contratação de empregados.

De acordo com as disposições originárias da Constituição de 1988 e da Lei nº 8.212/1991, o empregador rural pessoa jurídica está sujeito à tributação da contribuição previdenciária sobre a folha de salários, sendo devidas a cota patronal, com aplicação da alíquota de 20\%, e a contribuição ao RAT, com aplicação de alíquotas variáveis de 1\% a 3\% para financiar aposentadoria especial.

Com a entrada em vigor da Lei $n^{0} 8.870 / 1994$, alterada pela Lei $n^{0} 13.606 / 2018$, surgiu a possibilidade de o contribuinte optar pela incidência do tributo sobre a receita bruta decorrente da comercialização da produção, em substituição à cobrança sobre a folha de salários. Nessa linha, consoante dispõe o vigente art. 25 da Lei $n^{\circ}$ 8.870/1994, o tratado sujeito passivo poderá contribuir com $1,7 \%$ da receita bruta referida que, somada às contribuições ao RAT - à alíquota de $0,1 \%$ - e ao Serviço Nacional de Aprendizagem Rural (Senar) - à alíquota de 0,25\% -, totaliza o correspondente a 2,05\% da receita bruta da comercialização da produção própria.

Demais do exposto, é oportuno ressaltar que é facultado ao empregador rural pessoa jurídica escolher o regime tributário a que se sujeitará no ano-calendário, da mesma forma que ocorre com o empregador rural pessoa física. Assim, a regra geral aplicável consiste na incidência do tributo sobre a receita bruta oriunda do comércio da produção, ao passo que, para a contribuição devida incidir sobre a folha de salários, o sujeito passivo deverá manifestar sua opção expressamente mediante recolhimento do tributo sobre essa última base de cálculo mencionada.

\subsection{A AGROINDÚSTRIA}

Por último, cumpre tratar da pessoa jurídica denominada agroindústria, entendida como aquela que, além de desempenhar atividade de produção rural, desenvolve preponderantemente a industrialização da produção rural própria ou da produção rural própria e da produção adquirida de terceiros. Portanto, para o enquadramento da pessoa jurídica como agroindústria, é essencial que a industrialização da produção rural concorra para a consecução do objeto social da empresa.

Por se tratar de pessoa jurídica, originariamente a agroindústria se submeteu à incidência das contribuições previdenciárias - cota patronal e RAT - sobre a folha de salários. Em momento 
posterior, com a inclusão do art. 22-A na Lei $n^{0}$ 8.212/1991 feita por meio da Lei $n^{0} 10.256 / 2001$, estabeleceu-se incidência - em substituição à baseada na folha de salários - sobre a receita bruta proveniente da comercialização da produção, que vige atualmente. A sistemática de alíquotas prevista foi de 2,5\% destinados à seguridade social, mais 0,1\% para financiamento aos RAT e 0,25\% de contribuição ao Senar, resultando na aplicação de alíquota total de 2,85\% sobre a receita bruta oriunda da produção rural.

Ressalva-se, contudo, que, caso exista prestação de serviços pela agroindústria a terceiros, afasta-se a contribuição sobre faturamento para aplicar-se a exação incidente sobre a folha de salários, restando excluída a receita bruta correspondente aos serviços prestados da receita bruta total decorrente da produção, a teor do art. 22-A, parágrafos $2^{\circ}$ e $3^{\circ}$, da Lei n ${ }^{\circ}$ 8.212/1991.

Por fim, deve-se ressaltar outra exceção à regra geral vigente para a pessoa jurídica examinada, qual seja: não se sujeitam à analisada tributação substitutiva incidente sobre o faturamento as sociedades cooperativas e os produtores de peixe, aves, suínos e crustáceos. Igualmente, não está submetida à sistemática substitutiva a empresa que, quanto à atividade rural, dedique-se somente ao florestamento e reflorestamento para fornecer matéria-prima destinada à sua industrialização, por meio de processo industrial que altere a natureza química da madeira ou a transforme em pasta celulósica.

\section{PROBLEMAS DE CONSTITUCIONALIDADE RELATIVOS AO FUNRURAL}

Postas e apreciadas as regras atinentes aos diferentes sujeitos passivos que recolhem Funrural, passaremos ao estudo dos temas constitucionais relativos ao tributo em lume. A seguir, tratar-se-á especificamente da controvérsia já dirimida pelo Supremo Tribunal Federal.

\subsection{QUESTÃO JÁ DECIDIDA: O JULGAMENTO DO TEMA Nº 669 DA REPERCUSSÃO GERAL PELO STF}

No bojo do RE $n^{0} 718.874 / R S$, representativo da controvérsia afetada ao rito da repercussão geral em agosto de 2013 pelo Plenário do STF, debateu-se a constitucionalidade do Funrural devido pelo empregador rural pessoa física desde 2001, à luz das alterações realizadas pela Lei no 10.256. Relembre-se que a referida lei estabeleceu a incidência da contribuição sobre a receita bruta proveniente da comercialização da produção rural, em detrimento da folha de pagamentos. Isso 
ocorreu em momento posterior à EC nº 20/1998, responsável, a seu turno, por introduzir no ordenamento constitucional a receita como base imponível das contribuições sociais.

No caso concreto, a Procuradoria-Geral da Fazenda Nacional interpôs o apelo extraordinário contra acórdão do Tribunal Regional Federal (TRF) da $4^{\text {a }}$ Região que entendeu ser indevido o recolhimento do Funrural sobre a receita bruta decorrente da comercialização da produção para o empregador rural pessoa natural, nos termos da Lei $n^{o} 10.256 / 2001$. É de se destacar que o TRF da $4^{a}$ Região utilizou como premissa basilar os julgamentos do RE $\mathrm{n}^{\circ}$ 363.852/MG - conhecido por caso Mataboi -, no qual o Plenário do STF declarou a inconstitucionalidade das modificações trazidas pelo art. $1^{\circ}$ da Lei $n^{\circ} 8.540 / 1992$, bem como do RE $n^{0}$ 596.177/RS afetado ao rito da repercussão geral e que seguiu o mesmo entendimento já firmado.

Ressalta-se que as modificações operadas pela Lei $n^{\circ}$ 8.540/1992 conferiam nova redação ao art. 25 da Lei Orgânica da Seguridade Social, no sentido de instituir a incidência do Funrural sobre aquela receita bruta. No entanto, a Suprema Corte entendeu que essa base imponível não encontrava guarida na Constituição de 1988, porque na data de edição da lei inexistia previsão constitucional de incidência da contribuição sobre a receita. Assim, os incisos do art. 25 da Lei $n^{0}$ 8.212/19916 , com redação dada pela Lei $\mathrm{n}^{\circ}$ 8.540/1992 - nos quais foram estabelecidos os aspectos materiais da hipótese de incidência do Funrural -, restariam extirpados do ordenamento jurídico.

Dada a magnitude e complexidade da celeuma, diversos doutrinadores debruçaram-se sobre a temática no sentido de defender a inconstitucionalidade da exação. Dentre os variados estudos produzidos, realça-se o de Ávila (2011), consubstanciado em parecer, cuja leitura é recomendada.

Em que pesem as manifestações doutrinárias, em março de 2017, por maioria de votos, o STF decidiu ser constitucional o Funrural exigido do empregador rural pessoa física, a teor da EC $n^{\circ}$ 20/1998 e da Lei $n^{\circ}$ 10.256/2001. Na assentada, ficaram vencidos os ministros Edson Fachin, Rosa Weber, Ricardo Lewandowski, Marco Aurélio e Celso de Mello, ao passo que os demais julgadores acompanharam a divergência inaugurada pelo ministro Alexandre de Moraes.

Em apertada síntese, os fundamentos que conduziram a maioria vencedora foram: (i) a Lei $\mathrm{n}^{\mathrm{o}}$ 10.256/2001 apenas reintroduziu o empregador rural pessoa física como sujeito passivo do Funrural; (ii) a receita bruta da comercialização da produção seria mera espécie da base de cálculo receita, estipulada pela EC nº 20/1998; (iii) a nova base imponível estabelecida não consistiria em

\footnotetext{
6 “Art. 25. A contribuição da pessoa física e do segurado especial referidos, respectivamente, na alínea a do inciso V e no inciso VII do art. 12 desta lei, destinada à Seguridade Social, é de:

I - dois por cento da receita bruta proveniente da comercialização da sua produção;

II - um décimo por cento da receita bruta proveniente da comercialização da sua produção para financiamento de complementação das prestações por acidente de trabalho.”
} 
nova fonte de custeio, prescindindo de lei complementar; (iv) a tese firmada no julgamento sob repercussão geral do RE $n^{\circ}$ 596.177/RS valeria apenas para casos anteriores à Lei $\mathrm{n}^{\circ}$ 10.256/2001, pois o art. 25 da Lei nº 8.212/1991 manteve eficácia e vigência, apesar da declaração de inconstitucionalidade efetuada.

Ainda em 2017, diversos contribuintes opuseram embargos de declaração contra o acórdão, pretendendo a reversão do novel posicionamento e, subsidiariamente, a modulação dos efeitos da decisão tomada pelo STF.

Nesse sentido, invocou-se a Resolução $\mathrm{n}^{\circ}$ 15, de 12 de setembro de 2017, aprovada pelo Senado Federal com arrimo no art. 52, inciso X, da Constituição de 1988, como fato superveniente autorizador da reforma do precedente vinculante. É que, por meio deste ato do Poder Legislativo, a execução do art. 25, incisos I e II, da Lei nº 8.212/1991 - com redação dada pela Lei nº 8.540/1992 foi formalmente suspensa, ante a declaração de inconstitucionalidade pelo STF no caso Mataboi. Por conseguinte, tendo em mente que a Lei $\mathrm{n}^{0}$ 10.256/2001 não dispôs sobre os aspectos materiais da hipótese de incidência do Funrural, seria inviável a validade da cobrança da exação. Lado outro, com fins de demonstrar a necessidade de modulação de efeitos, suscitou-se a mudança abrupta do entendimento jurisprudencial do Supremo a respeito da temática, demandando aplicação do art. 927, parágrafo 3º do Código de Processo Civil (CPC) de 2015 ao caso.

Dando contornos definitivos à questão, em maio de 2018, o Plenário do STF rejeitou por maioria de votos todos os embargos de declaração opostos, afastando a possibilidade de modulação dos efeitos da decisão tomada. Segundo a maioria dos ministros, a Resolução nº 12/2017 do Senado Federal não se referiu à cobrança da exação prevista pela Lei ${ }^{\circ} 10.256 / 2001$, consolidando que o ato em foco e o caso Mataboi não têm o potencial de alterar o que foi decidido pela Suprema Corte.

Não obstante as diversas e pertinentes críticas ao posicionamento da Corte constitucional, restou a matéria pacificada. Nessa linha, em raciocínio similar àquele há muito referenciado por Sacha Calmon Navarro Coêlho no sentido da supremacia do Poder Judiciário (COÊLHO, 2016, p. 3), a decisão em foco corrobora a assertiva de que esse Poder possui a última palavra no que tange à interpretação das leis. Roma locuta, tollitur quaestio.

\subsection{CONTROVÉRSIAS A DECIDIR PELO STF}

Passemos agora ao exame dos temas que pendem de apreciação pela Suprema Corte. 


\subsubsection{O tema $\mathrm{n}^{0} 723$ da repercussão geral: o segurado especial pode recolher o Funrural sobre a receita bruta?}

Outra temática com repercussão geral reconhecida relacionada a contribuição do Funrural que se apresenta para a Suprema Corte é a posta no RE $n^{\circ} 761.623 / S C$, cujo relator é o ministro Alexandre de Moraes. Este caso trata da constitucionalidade da contribuição previdenciária devida pelo produtor rural em regime de economia familiar - segurado especial -, de sorte que se questiona precisamente se o “resultado da comercialização” é equiparável a "receita bruta”, para fins de incidência tributária. Nessa exata medida, os contribuintes sustentam a diferenciação entre as duas previsões legislativas, bem como suscitam a inconstitucionalidade formal da tributação sobre a receita bruta estabelecida no art. 25 da Lei $n^{\circ}$ 8.212/1991.

A matéria em questão é de extrema pertinência e nos obriga a investigar se houve criação de nova fonte de custeio da seguridade social sem observância dos requisitos constitucionais, assim como depurar os contornos delineados pela Constituição e pelo STF a respeito de receita bruta. Frisese que não há a pretensão de delimitar exaustivamente um conceito do instituto, mas tão somente contribuir para o debate, de forma analítica em relação às regras vigentes.

$A b$ initio, para a apreciação da questão, há que se ter em mente os conceitos referentes à receita, moldados com o passar do tempo pela doutrina e pelos pronunciamentos do Supremo.

Recorrendo às lições de Ives Gandra da Silva Martins (2017, p. 8) e Schubert de Farias Machado (2017, p. 93), entende-se que a receita - ou receita bruta - consiste na integralidade dos ingressos financeiros da entidade que decorram de atividade econômica vinculada ao objeto social ou não e que passe a pertencer à sociedade, integrando seu patrimônio. Assim, o instituto jurídico receita pressupõe maior abrangência, especialmente no que concerne às entradas que provocam aumento patrimonial com suas respectivas causas ou origens.

Diante disso, pode-se visualizar a receita como gênero que compreende diversas espécies, dentre as quais se destaca a receita bruta operacional. Entende-se que esta corresponde apenas aos ingressos da entidade oriundos exclusivamente da consecução do objeto social da empresa, porém, a temática específica da receita bruta operacional ainda pende de apreciação pelo STF, especificamente no RE $n^{0}$ 609.096/RS.

Por oportuno, é dizer que essa compreensão sobre a receita enquanto gênero abarcador de diversas espécies foi adotada pelo Plenário do STF no julgamento do RE $n^{\circ}$ 346.084/PR, que tratou da inconstitucionalidade do alargamento da base de cálculo da contribuição ao PIS e da Cofins não 
cumulativas promovido pelo art. $3^{\circ}$, parágrafo $1^{\circ}$, da Lei $n^{\circ} 9.718 / 1998^{7}$. Nessa assentada, a Suprema Corte brasileira definiu o alcance do termo faturamento, pelo que o equiparou à receita bruta proveniente das vendas de mercadorias, ou prestação de serviços, ou de mercadorias e prestação de serviços (BRASIL, 2006).

Importante registro foi feito pelo Ministro Cézar Peluso, que, apesar de ter sido voto vencido, delimitou ainda mais o conceito de faturamento, que consistiria na receita bruta derivada da venda de bens e/ou prestação de serviços enquanto produto das atividades empresariais típicas. Outrossim, o citado ministro delimitou que o termo receita bruta abarca todas as receitas auferidas pela pessoa jurídica, incluindo as não operacionais, consolidando a compreensão, a nosso ver acertada, de que a receita é gênero que compreende diversas espécies (BRASIL, 2006).

Em face disso, possível concluir que, ao predicar a incidência do Funrural sobre a receita bruta, o legislador infraconstitucional previu tributação sobre todos os ingressos financeiros do segurado especial que guardem pertinência com a venda da produção rural realizada com fins de subsistência. Contudo, parece-nos inadequado entender que a predicada incidência sobre a receita bruta decorrente da comercialização da produção corresponde à previsão constitucional de incidência sobre o resultado da comercialização da produção, por algumas razões.

Primeiramente, é dizer que, no que tange ao financiamento da seguridade social, a norma constitucional autorizou exclusivamente a tributação das receitas auferidas por empregadores, empresas e entidades a elas equiparáveis, a teor do art. 195, inciso I, alínea b, da Constituição:

\footnotetext{
Art. 195. A seguridade social será financiada por toda a sociedade, de forma direta e indireta, nos termos da lei, mediante recursos provenientes dos orçamentos da União, dos Estados, do Distrito Federal e dos Municípios, e das seguintes contribuições sociais:

I - do empregador, da empresa e da entidade a ela equiparada na forma da lei, incidentes sobre:

[...]

b) a receita ou o faturamento; [...]. (BRASIL, 1988).
}

Nesse sentido, entende-se que o segurado especial - produtor rural pessoa física em regime de economia familiar - não é destinatário de tributo incidente sobre receita, pois não se trata de empregador, empresa ou entidade a ela equiparada por força da lei. Destarte, deve-se relembrar que, ao estabelecer o resultado da comercialização da produção rural como base imponível, a Constituição

\footnotetext{
${ }^{7}$ Este precedente foi julgado em conjunto com os REs $n^{\circ} 390.840 / M G, n^{\circ} 358.273 / R S$ e $n^{\circ} 357.950 / R S$, leading cases sobre o tema.
} 
estabeleceu verdadeira regra especial para o segurado especial, justificável na medida em que desempenha suas atividades sem auxílio de empregados ${ }^{8}$.

Nota-se, por conseguinte, a primeira razão para a impossibilidade de exigir-se do segurado especial o Funrural sobre a receita bruta - espécie de receita - decorrente da comercialização da produção, sendo irrelevante para este sujeito passivo a superveniência da EC nº 20/1998.

Nessa medida, conferir constitucionalidade à tratada exação, importa em subverter a norma constitucional. Isso pois pressupõe afrontoso reconhecimento de que a pessoa física aufere receita, sem que este sujeito passivo figure no texto expresso do art. 195, inciso I, alínea b, da Constituição, bem como sem a equiparação do produtor rural em regime de economia familiar à empresa.

Dessarte, para que a incidência do Funrural devido pelo segurado especial sobre a receita bruta fosse válida, seria imprescindível sua veiculação por lei complementar, na medida em que se trata de tributo criado com base na competência residual da União. Afinal, o produtor rural pessoa física em regime de economia familiar não figura como sujeito passivo das contribuições incidentes sobre faturamento e receita, predicadas no art. 195, inciso I, alínea b, da Constituição de 1988.

Nessa perspectiva, denota-se a inexistência de previsão de que a segurado especial aufere receita, na medida em que não é pessoa jurídica ou entidade equiparada a pessoa jurídica. Indo adiante, é plausível depreender que a expressão “resultado da comercialização da produção rural” do produtor rural em regime de economia familiar - não corresponde ao mero ingresso de recursos oriundos da venda da produção. A razão para tanto reside na ideia de que o resultado pressupõe um confronto entre os ingressos que incrementaram o patrimônio da pessoa física com as despesas ou custos incorridos para a realização daquela produção, sobretudo diante da situação a que está submetida esta espécie de produtor, qual seja: desempenho de atividade rural de modo indispensável para sua subsistência e para o desenvolvimento socioeconômico do seu núcleo familiar, sem auxílio de empregados. Assim, é inviável que a contribuição do Funrural devida pelo produtor rural em regime de economia familiar seja exigida com base na receita bruta.

A propósito, sublinhe-se que, nos autos do já citado RE nº 363.852/MG, o Ministro Cezar Peluso realizou idêntico apontamento em seu voto-vista, acompanhando o voto condutor:

Ora, a contribuição sobre o resultado da comercialização da produção rural do art. 195, § $8^{\circ}$, existe precisamente porque seu destinatário - o produtor rural sem empregados permanentes - não pode, é óbvio, contribuir sobre folha de salários, faturamento ou receita, já que não dispõe de empregados, nem é pessoa jurídica ou entidade a ela equiparada. (BRASIL, 2010).

\footnotetext{
${ }^{8}$ No mesmo sentido, é ver os ensinamentos de Humberto Ávila, estendendo as razões da tributação especial para um viés de consecução da isonomia: “[...] a Constituição reserva o resultado da comercialização da produção como base de cálculo da contribuição do segurado especial [...]. Essa base de cálculo diferenciada justifica-se pela impossibilidade da cobrança das contribuições sociais sobre as outras bases: não se pode exigir dele a contribuição sobre a folha de salários porque não tem empregados; [...].” (ÁVILA, 2011, p. 137).
} 
Partindo deste raciocínio, compreende-se que o resultado da comercialização da produção rural não corresponde a todos os ingressos de recursos oriundos da operação mercantil, o que corrobora a inviabilidade de incidência do Funrural sobre a receita bruta. Em contrapartida, há que se ressaltar que o resultado da comercialização da produção pressupõe, em tese, confronto dos ingressos de recursos com as despesas para manutenção da fonte produtora, dentre as quais residem aquelas incorridas para a própria efetivação da produção.

Diante disso, parece-nos que a expressão predicada no art. 195, parágrafo $8^{\circ}$, da Constituição de 1988, guarda maior proximidade com o conceito de renda, uma vez que aponta para a ideia de resultado positivo, assim como pelo fato de a pessoa física apenas auferir renda para fins tributários, de acordo com o ordenamento jurídico vigente. Acerca da renda, valemo-nos do que diz Fonseca em um dos capítulos que dedica à construção de um conceito jurídico do instituto: “[...] renda é um fluxo de riqueza nova que acresce ao patrimônio do titular, mensurada entre dois pontos previamente estabelecidos, desde que preservada a fonte produtora, o que impõe a necessidade de manutenção do capital e a compensação integral das perdas acumuladas.” (FONSECA, 2018, p. 145).

Ademais, é dizer que, em regra, para o produtor rural pessoa física em regime de economia familiar, a produção rural se traduz em verdadeiro produto do trabalho desempenhado, de sorte que parte daquilo gerado é utilizado para sobrevivência e a outra parte é destinada à comercialização com fins de manutenção e desenvolvimento socioeconômico do núcleo familiar. Por conseguinte, averigua-se a proximidade entre o resultado da comercialização da produção rural e a aquisição da disponibilidade econômica do produto do trabalho.

Portanto, não se vislumbra a possibilidade de o Funrural devido pelo segurado especial incidir sobre a receita bruta, sobretudo ante ausência de previsão expressa de auferimento de receita por pessoa física e em face da expressão “resultado da comercialização da produção rural” da pessoa física aproximar-se mais do conceito de renda. Nada obstante, há que se aguardar o pronunciamento definitivo do STF no julgamento do caso paradigma, que resultará em precedente vinculante a dirimir a controvérsia.

\subsubsection{Empregador rural pessoa jurídica pode ser obrigado a pagar Cofins cumulativamente com Funrural, em face da identidade das bases de cálculo das exações?}

Outra controvérsia submetida à Suprema Corte brasileira consiste na constitucionalidade da contribuição substitutiva do Funrural incidente sobre a receita bruta exigido das pessoas jurídicas empregadoras rurais - conforme estabelecido pelas Leis $n^{\circ}$ 8.870/1994 e $n^{\circ}$ 10.256/2001 -, tendo em 
mente a existência da Cofins. Frise-se que há dois casos pertinentes à matéria no STF, com repercussão geral reconhecida: RE $n^{\circ}$ 611.601/RS, relativo às agroindústrias (art. 22-A da Lei $n^{\circ}$ 8.212/1991); e RE no 700.922/RS, referente às agropecuárias (art. 25 da Lei $\mathrm{n}^{\circ}$ 8.870/1994). Resumidamente, o questionamento levado é: o empregador pessoa jurídica pode ser compelido a pagar Cofins e Funrural simultaneamente, considerando a identidade de bases de cálculo e regra matriz?

Os contribuintes - naturalmente contrários a essa possiblidade - sustentam sobretudo que a instituição da contribuição do Funrural sobre a receita bruta proveniente da comercialização da produção rural subverte o Sistema Tributário nacional, pois há nítida dupla incidência - bis in idem - sobre a mesma materialidade, qual seja, o faturamento ${ }^{9}$. Em contrapartida, a União defende a constitucionalidade da cobrança baseada no permissivo do art. 195, inciso I, da Constituição de 1988, que predica incidência de contribuições sociais sobre faturamento desde o texto originário.

No tocante específico ao tema afeito às bases de cálculos dos tributos, certo é que a Suprema Corte brasileira há muito já consolidou posicionamento convalidando que a contribuição tenha base imponível coincidente com a do imposto.

Segundo este raciocínio, inexiste vedação constitucional expressa que impeça instituição de contribuições incidente sobre mesmo fato gerador e com a mesma base de cálculo dos impostos, sobretudo tendo em vista que esta restrição existe exclusivamente para as taxas, a teor do art. 145, parágrafo $2^{\circ}$, da Constituição de 1988. Esta interpretação foi consubstanciada pelo Plenário do STF nos REs n ${ }^{\circ} 177.137 / R S, n^{\circ} 165.939 / R S$ e 228.321/RS, na década de 90, o que se extrai do voto proferido pelo Ministro Carlos Velloso no último referido recurso:

\begin{abstract}
Destaco dos votos que proferi nos citados RREE 177.137-RS e 165.939-RS:
“A contribuição parafiscal ou especial é um terceiro gênero. Vale dizer, não é imposto e não é taxa. Quando do julgamento do RE 138.284-CE, de que fui relator, examinei o tema em pormenor (RTJ 143/313). A ele me reporto. [...]

[...] A contribuição, não obstante um tributo, não está sujeita à limitação inscrita no $\S 2^{\circ}$ do art. 145 da Constituição. Também não se aplicam a ela as limitações a que estão sujeitos os impostos, em decorrência da competência privativa dos entes políticos para instituí-los (CF, arts. 153, 155 e 156), a impedir a bitributação.” (BRASIL, 2003).
\end{abstract}

Repisando o tema sob o rito da repercussão geral em 2017, o STF reiterou o entendimento pacificado pelo Plenário em assentada que avaliou a possibilidade de bitributação na instituição da contribuição sindical rural no bojo do RE $n^{\circ}$ 883.542/SP, sendo que o ministro relator Gilmar Mendes invocou como ratio decidendi o mencionado voto proferido pelo ministro Carlos Velloso.

\footnotetext{
${ }^{9}$ Conforme tratado alhures, nos moldes em que foi declarado pelo STF, o faturamento consiste na receita bruta proveniente das vendas de mercadorias, de serviços e de mercadorias e serviços.
} 
A seu turno, como é cediço, deve-se salientar que há possibilidade de existência de duas contribuições incidentes sobre a mesma base tributável, nas hipóteses em que o fundamento de validade constitucional delas é distinto ${ }^{10}$. Isto é, desde que a Constituição autorize expressamente a incidência sobre a mesma materialidade, como nos casos da Cofins e da contribuição ao PIS/Pasep, das contribuições sobre a folha de salários e daquelas destinadas ao financiamento das entidades privadas. Nessa perspectiva, confira-se o seguinte excerto do voto do Ministro Moreira Alves proferido no julgamento da $\mathrm{ADC} \mathrm{n}^{\circ} 01 / \mathrm{DF}$ :

De outra parte, sendo a COFINS contribuição social instituída com base no inciso I do artigo
195 da Constituição Federal, e tendo ela natureza tributária diversa do imposto, as alegações
de que ela fere o princípio constitucional da não-cumulatividade dos impostos da União e
resulta em bitributação por incidir sobre a mesma base de cálculo do PIS/PASEP só teriam
sentido se se tratasse de contribuição social nova, não enquadrável no inciso I do artigo 195,
[...]
[...]
Ademais, no tocante ao PIS/PASEP, é a própria Constituição Federal que admite que o
faturamento do empregador seja base de cálculo para essa contribuição social e outra, como,
no caso, é a COFINS. De feito, se o PIS/PASEP, que foi caracterizado pelo artigo 239 da
Constituição, como contribuição social por lhe haver dado esse dispositivo constitucional
permanente destinação previdenciária, houvesse exaurido a possibilidade de instituição, por
lei, de outra contribuição social incidente sobre o faturamento dos empregadores, essa base
de cálculo, por já ter sido utilizada, não estaria referida no inciso I do artigo 195 que é o
dispositivo da Constituição que disciplina, genericamente, as contribuições sociais, e que
permite que, [...], seja a seguridade social financiada por contribuição social incidente sobre
o faturamento dos empregadores. (BRASIL, 1995).

Por outro lado, a controvérsia a ser analisada pelo STF quanto à existência de bis in idem em face das pessoas jurídicas empregadoras rurais, não deve ser influenciada pelos entendimentos jurisprudenciais expostos. Isso porque não se trata de criação de contribuição com base imponível de imposto, tampouco de contribuições incidente sobre materialidade idêntica com fundamentos de validade constitucional distintos.

Em verdade, parece-nos que assiste razão aos contribuintes, porque as estruturas das hipóteses de incidência da Cofins e da contribuição do Funrural são coincidentes, com plena identidade entre os aspectos materiais e pessoais respectivos. Nessa medida, nota-se que a base tributável prevista para incidência do Funrural - receita bruta proveniente da comercialização da produção rural - corresponde ao faturamento, nos moldes em que foi delineado pelo STF, razão pela qual é nítido que o mesmo signo presuntivo de riqueza foi gravado em duplicidade.

Ademais e não menos importante, deve-se sublinhar que o fundamento de validade das contribuições em lume é o mesmo, qual seja o art. 195, inciso I, alínea b, da Constituição de 1988,

\footnotetext{
${ }^{10}$ Interessante sublinhar ensinamento de Regina Helena Costa sobre o bis in idem que se traduz "na situação de o mesmo fato jurídico ser tributado mais de uma vez pela mesma pessoa política, sendo permitido pelo sistema pátrio desde que expressamente autorizado pela Constituição.” (COSTA, 2009, p. 50).
} 
pelo que impossível a coexistência da exigência da Cofins e da contribuição ao Funrural. É que a competência tributária predicada pelo citado dispositivo constitucional foi esgotada pela instituição da Cofins, estabelecida na Lei Complementar nº 70/1991, gravando a base tributável em foco sem poder repeti-la. A respeito da impossibilidade desta repetição, veja-se lição de Ávila:

Da mesma forma, a regra de competência, por exemplo, que atribui exclusivamente à União o poder de instituir contribuição social sobre a receita, executa a tarefa de limitar o comportamento do referido ente federado de modo a que ele só possa exercer legitimamente sua competência no tocante a essa base de cálculo e não a outras, inclusive porque, em relação a outras bases de cálculo a referida competência só pode ser validamente exercida por meio de outra fonte e sem repetir as bases de cálculo já previstas [...]. (ÁVILA, 2018, p. 28).

Portanto, ante as considerações expostas, entende-se que é acertado o posicionamento no sentido da inconstitucionalidade da instituição do Funrural incidente sobre receitas brutas da comercialização da produção rural, exigido das agroindústrias e das agropecuárias, na medida em que as contribuições em foco têm o mesmo fundamento constitucional, configurando o bis in idem vedado pela Constituição. Outrossim, ressalva-se que aguardamos o pronunciamento do STF, porém parecenos que ante o dever de coerência jurisprudencial, deverá a Corte constitucional invalidar a exigência em face das pessoas jurídicas empregadoras rurais, mantendo a Cofins e reestabelecendo apenas a contribuição sobre a folha de salários.

\subsubsection{Alcance da imunidade das receitas de exportação no caso dos produtores rurais}

À guisa de desfecho sobre as controvérsias constitucionais, deve-se perquirir sobre tema que relaciona as contribuições sociais - dentre as quais, incluído o Funrural - e a imunidade das receitas de exportação, de modo que seja delimitado se esta imunidade abarca as receitas provenientes das denominadas exportações indiretas, impedindo a incidência das contribuições.

A respeito da referida exportação indireta, é dizer que há habitualidade desta prática no setor, pois diversas vezes os produtores rurais não dispõem dos meios para consecução da exportação, pelo que lançam mão das cooperativas e das denominadas trading companies ou empresas comerciais exportadoras. Outrossim, a título de breve esclarecimento sobre a sistemática desta forma de exportação, registre-se que: (i) no caso da modalidade via cooperativas, o associado pratica ato cooperativo, predicado no art. 79 da Lei ${ }^{\circ}$ 5.764/1971, que não implica contrato de compra e venda de produto; ao passo que (ii) no caso das operações via trading companies, o produtor vende sua produção à empresa exportadora, sendo que esta operação goza de imunidade, na medida em que este direito é estendido por força do art. $1^{\circ}$ do Decreto-lei n ${ }^{\circ} 1.248 / 1972$. 
Diante disso, os questionamentos constitucionais que se apresentam visam sanar se as operações feitas com as cooperativas e as vendas endereçadas às trading companies para exportação subsequente são alcançadas pela imunidade objetiva predicada pelo art. 149, parágrafo $2^{\circ}$, da Constituição.

Assevere-se que parte da temática a ser aqui tratada será julgada pelo STF, nos autos do RE $\mathrm{n}^{\circ}$ 759.244/SP, afetado à sistemática da repercussão geral. Neste caso paradigmático, analisar-se-á o alcance da regra imunizante para as agroindústrias que exportam sua produção mediante empresas comerciais exportadoras, abalizando se as operações entre estas pessoas jurídicas estão sujeitas à incidência das contribuições sociais. A questão foi alçada à Suprema Corte brasileira sobretudo em razão da existência de atos infralegais ${ }^{11}$ expedidos pela administração fazendária que, segundo os contribuintes, limitam indevidamente a regra imunizante em foco. É que, no entendimento do fisco, as receitas decorrentes da comercialização com empresas constituídas e em funcionamento no Brasil são consideradas como oriundas do comércio interno, a despeito da destinação que será dada à produção rural.

Nada obstante, entende-se que a solução para as questões propostas perpassa pelos conceitos e efeitos da imunidade, bem como pela teleologia da norma imunizante extraída do art. 149, parágrafo $2^{\circ}$, da Constituição de 1988, vinculada a valores constitucionais e sua preservação no tempo (COÊLHO, 2018, p. 158).

No tocante ao conceito de imunidade tributária, remetemo-nos à lição de Paulo de Barros Carvalho, de acordo com o qual, consiste nas normas jurídicas estabelecidas no texto constitucional que preveem expressamente a incompetência do poder de tributar determinadas situações (CARVALHO, 2000, p. 179). Igualmente valiosos são os ensinamentos de Baleeiro atualizados por Misabel Derzi, que divergem em certa medida do conceito destacado anteriormente:

A imunidade é regra constitucional expressa (ou implicitamente necessária) que estabelece a não-competência das pessoas políticas da federação para tributar certos fatos e situações, de forma amplamente determinada, delimitando negativamente, por meio de redução parcial, a norma de atribuição de poder tributário. A imunidade é, portanto, regra de exceção e de delimitação de competência, que atua, não de forma sucessiva no tempo, mas concomitantemente. (BALEEIRO, 2006, p. 228).

Noutro enfoque, tratando da atuação da imunidade na hipótese de incidência, Coêlho (2018, p. 158) sublinha que o “dispositivo constitucional que põe a imunidade atua na hipótese de incidência excluindo de certos fatos ou aspectos destes a virtude jurígena.”

\footnotetext{
${ }^{11}$ Inicialmente a restrição questionada foi predicada na Instrução Normativa da Secretária da Receita Previdenciária (SRP) $n^{\circ}$ 03/2005. Atualmente, a previsão se encontra na Instrução Normativa da Receita Federal do Brasil (RFB) nº 971/2009, especificamente no art. 170 , parágrafo $2^{\circ}$.
} 
Por seu turno, adentrando à questão teleológica, é notório que o fim da imunidade em estudo é exortar as exportações, ao afastar as contribuições sociais incidentes sobre as receitas decorrentes de exportação. Desse modo, visa-se garantir o superávite da balança comercial pátria, o que inquestionavelmente realiza os objetivos-deveres fundamentais da soberania e do desenvolvimento nacional, predicados no art. $1^{\circ}$, inciso I, e no art. $3^{\circ}$, inciso II, ambos da Constituição de 1988.

Destaque-se que é assente no entendimento jurisprudencial do STF que o tema das imunidades demanda a referida interpretação teleológica, em atenção ao escopo do que foi pretendido pelo legislador constituinte. Disso resulta a ampliação dos enunciados imunizantes para abarcar fatos ou objetos não abrangidos pela expressão literal do texto constitucional. A título exemplificativo, trazemos a lume precedente vinculante - $R E n^{\circ}$ 627.815/PR, afetado ao rito da repercussão geral - da Suprema Corte, no qual se fixou tese da inconstitucionalidade da incidência da contribuição ao PIS e da Cofins sobre receita decorrente da variação cambial positiva obtida nas operações de exportação de produtos. Deste caso, é essencial extrair apontamento da Ministra Relatora Rosa Weber, concernente à finalidade da imunidade objetiva estudada:

Corrobora, por fim, o presente posicionamento, o fato de a imunidade em questão não ser
concedida apenas às “receitas de exportação”, senão às “receitas decorrentes de exportação”
(art. 149, $\S 2^{\circ}$, I). O adjetivo “decorrentes” confere maior amplitude à desoneração
constitucional, suprimindo do alcance da competência impositiva federal todas as receitas
que resultem da exportação, que nela encontrem a sua causa, representando consequências
financeiras do negócio jurídico de compra e venda internacional; evidencia por consequência,
a intenção, plasmada na Carta Política, de se desonerarem as exportações por completo, a fim
de que as empresas brasileiras não sejam coagidas a exportarem os tributos que, de outra
forma, onerariam as operações de exportação, quer de modo direto, quer indireto. (BRASIL,
2013a).

Trazendo-se os argumentos em abstrato para as questões concretas, entende-se que deverá ser novamente adotada interpretação ampliativa da imunidade - encampada pelo STF - tanto para as exportações feitas por meio de cooperativas, quanto para aquelas realizadas mediante trading companies. Isso eis que não há que se dizer que o enunciado imunizante tem aplicação restrita à exportação direta, de forma que para fruição dessa imunidade fiscal é unicamente relevante que a finalidade da operação seja a exportação - independentemente dos meios para sua realização - e não a venda interna da produção rural.

Nessa medida, deve-se reconhecer que estão contempladas pela imunidade tributária as operações anteriores feitas com a cooperativa ou com a empresa comercial exportadora, essenciais para realização da exportação. Portanto, entende-se que é inviável a cobrança das contribuições sociais incidentes sobre as receitas provenientes destas operações prévias à exportação. Esse entendimento atende à teleologia da imunidade das exportações, estimulando as exportações das 
produções rurais que desempenham função preponderante no Brasil, sobretudo no atual cenário de crise fiscal, como visto no tópico introdutório.

Desse modo, crê-se que o STF deverá convalidar o entendimento das agroindústrias na assentada que julgar o $\mathrm{RE} \mathrm{n}^{0}$ 759.244/SP - paradigma da repercussão geral -, promovendo a extensão da imunidade para as receitas auferidas nas operações de transferência da produção rural feitas entre o contribuinte agroindustrial e a trading company, com fim último de exportação. Lado outro, aguardar-se-á que a questão pertinente às exportações intermediadas pelas cooperativas seja alçada à Corte constitucional, adiantando-se que estas operações também deverão ser abrangidas pela imunidade das exportações.

\section{QUESTÕES EM JULGAMENTO PELO CARF ATINENTES AO FUNRURAL}

Explorados os temas constitucionais relacionados à contribuição previdenciária em foco, trataremos algumas das questões jurídico-tributárias recentemente postas à apreciação do Conselho Administrativo de Recursos Fiscais (Carf), neste tópico.

\subsection{A DELINEAÇÃO DAS RECEITAS INCLUÍDAS NA BASE TRIBUTÁVEL DO FUNRURAL DEVIDO PELOS PRODUTORES RURAIS PESSOAS JURÍDICAS}

Controvérsia atual que costumeiramente é submetida a apreciação do Carf é a referente a quais receitas são tributadas pelo Funrural nas pessoas jurídicas de direito privado produtoras rurais - agroindústria e agropecuária -, analisada alhures. Isto é: o que está encampado pela expressão receita bruta proveniente da comercialização da sua produção?

A Receita Federal do Brasil (RFB) considera que as receitas decorrentes de atividades que vão além da atividade rural ou industrial devem integrar a base imponível do Funrural, excetuandose aquelas originadas pela prestação de serviços a terceiros ${ }^{12}$. Dessa forma, o fisco pretende incluir todas as receitas da pessoa jurídica em questão naquela base tributável, como, por exemplo, as receitas originadas pela revenda de mercadorias.

Entretanto, os dispositivos legais que preveem as contribuições previdenciárias em questão predicam o gravame sobre o resultado da comercialização da produção rural própria, para as agropecuárias. Assim, somente as operações que importem em comercialização da produção própria estão abrangidas pela incidência tributária, restando excluídas as revendas e devoluções referentes a

\footnotetext{
${ }^{12}$ A título exemplificativo, veja-se o entendimento consolidado na Solução de Consulta Cosit nº 34/2016.
} 
aquisições de produtos de terceiros. É exatamente a noção restrita acerca do resultado da comercialização da produção que inviabiliza inclusão de outras espécies de receita.

Por seu turno, cumpre salientar que, no caso específico da agroindústria, o Funrural somente incide sobre a comercialização que tenha por objeto a produção própria ou de terceiros que seja por ela industrializada. Por conseguinte, meras revendas de produção de terceiros que não sofreram processo de industrialização próprio da agroindústria não autorizam a exigência tributária.

Tratando-se da inclusão das receitas oriundas de revenda especificamente, o Carf já se manifestou concluindo que elas não compõem a base de cálculo da contribuição do Funrural. Cuidase do acórdão n ${ }^{\circ}$ 2202-003.765 proferido pela $2^{\text {a }}$ Turma Ordinária da $2^{\text {a }}$ Câmara do Carf, que restou assim ementado, para o que aqui interessa:

PRODUTOR RURAL PESSOA JURÍDICA. CONTRIBUIÇÃO SOBRE A RECEITA BRUTA DA COMERCIALIZAÇÃO DE SUA PRODUÇÃO RURAL. [...]. REVENDA. AVES MATRIZES. DEVOLUÇÃ̃O DE NOTAS FISCAIS.

São devidas pelo produtor rural pessoa jurídica, as contribuições incidentes sobre a receita bruta proveniente da comercialização de sua produção rural, em substituição às contribuições incidentes sobra à [sic] folha de pagamento.

Devem ser afastadas da base de cálculo das referidas contribuições o que foi objeto de comercialização, porém a produção comercial foi de outrem, como no caso de revendas, bem como quando do descarte de aves matrizes.

Com a comprovação de que houve devolução de mercadorias, igualmente devem ser afastadas da base de cálculo tais receitas. (BRASIL, 2018a).

Noutro caso, avaliando temática similar afeita exclusivamente à agroindústria, a $1^{\text {a }}$ Turma Ordinária da $2^{\text {a }}$ Câmara do Carf determinou a não inclusão do ICMS substituição tributária na receita da comercialização da produção, na medida em que este imposto não pode ser considerado receita do contribuinte. Confira-se excerto da ementa do acórdão nº 2201-004.687:

CONTRIBUIÇÃO SOCIAL. AGROINDÚSTRIAS. BASE DE CÁLCULO. EXCLUSÃO. ICMS SUBSTITUIÇÃO.

A contribuição para a seguridade social das agroindústrias prevista no art. 22-A da Lei $n^{\circ}$ 8.212, de 1991, incide sobre a receita bruta, que é integrada pelo ICMS. Contudo, o mesmo entendimento não se aplica no caso de ICMS destacado na condição de substituto tributário (ICMS-ST).

O valor destacado na nota de venda como ICMS-ST é um reembolso pago pelo comprador (substituído) pelo recolhimento do tributo efetuado antecipadamente pelo vendedor (substituto). Assim, referidos valores são meros ingressos na contabilidade da empresa substituta que se torna apenas depositária de tributo.

Desta forma, o ICMS-ST não pode ser considerado receita da empresa vendedora (substituta), não sendo, portanto, base de incidência das contribuições previdenciárias calculadas sobre a receita bruta. (BRASIL, 2018b).

Consequentemente, percebe-se que, como na maior parte das controvérsias, a solução adequada deve perpassar as particularidades fáticas da lide. Nessa linha, entende-se que o posicionamento da RFB não prospera sem questionamentos, pelo que a base tributável do Funrural 
devido pelas pessoas jurídicas produtoras rurais deve ser aferida em cada caso concreto, observada a necessidade de estar relacionada à atividade rural.

\subsection{OS REQUISITOS RELACIONADOS A ATIVIDADE RURAL DESEMPENHADA PELAS PESSOAS JURÍDICAS ENSEJADORES DA EXIGÊNCIA SUBSTITUTIVA DO FUNRURAL}

Conforme visto, os produtores rurais pessoas jurídicas desempenham - por meio de contratação de empregados - atividade de produção e venda dos produtos rurais sem submetê-los a processos de beneficiamento ou industrialização. Consultando-se o art. 165, inciso I, alínea b, da IN RFB n 971/2009 a título complementar, depreende-se que se considera produtor rural a pessoa jurídica que tenha como fim somente a atividade de produção rural; isto é, para o enquadramento enquanto produtor rural, há que se desempenhar exclusivamente atividade voltada à produção rural.

Indo adiante e como visto alhures, sabe-se que, conforme a legislação atual, o empregador rural pessoa jurídica pode optar por financiar a seguridade social mediante contribuição incidente sobre a folha de salários - cota patronal -; ou substitutivamente, por meio da contribuição ao Funrural, incidente sobre receita bruta proveniente da comercialização da produção.

Para a substituição em questão, é de sobrelevada relevância que seja conferida à pessoa jurídica a natureza de produtor rural, na medida em que somente aquela entidade que se dedique exclusivamente à produção rural poderá se sujeitar à substituição da incidência tributária.

Nessa linha, é essencial destacar que o art. 175, parágrafo $2^{\circ}$, inciso III, da IN RFB $\mathrm{n}^{\circ}$ 971/2009 estabelece que o regime substitutivo não será aplicável quando o produtor rural pessoa jurídica: (i) prestar serviços a terceiros em condições que não caracterize atividade econômica autônoma, exclusivamente em relação à remuneração dos segurados envolvidos na prestação dos serviços, excluída a receita proveniente destas operações da base imponível das contribuições; ou (ii) exercer outra atividade econômica autônoma, de natureza comercial, industrial ou de serviços, em relação à remuneração dos empregados e trabalhadores avulsos (BRASIL, 2009).

Destarte, a consequência disso é extremamente relevante, porque a pessoa jurídica que não se dedicar exclusivamente ao desempenho da atividade voltada à produção rural deverá recolher contribuição previdenciária sobre a folha de salários (art. 22 da Lei $n^{\circ}$ 8.212/1991), vedado o recolhimento ao Funrural. Ao apreciar essa questão, o Carf exarou o entendimento que preconiza o desempenho exclusivo da atividade rural para que a pessoa jurídica faça jus ao regime tributário que substituiu a contribuição sobre folha de salários pela contribuição ao Funrural. Assim, é conferir excerto do acórdão $n^{\circ}$ 2401-002.284: 
PRODUTOR RURAL PESSOA JURÍDICA. REGIME DE TRIBUTAÇÃO SUBSTITUTIVO. PRESSUPOSTOS. EXPLORAÇÃO DE OUTRAS ATIVIDADES. NÃO ENQUADRAMENTO.

Somente poderá fazer jus ao pagamento da contribuição substitutiva incidente sobre a receita bruta proveniente da comercialização da produção rural, inscrita no artigo 25 da Lei ${ }^{\circ}$ 8.870/1994, o produtor rural pessoa jurídica, exceto a agroindústria, que não desenvolva outra atividade autônoma, o que não se vislumbra no caso vertente, onde a autuada, além da atividade rural, explora outras atividades de aluguel, incorporação imobiliária e exploração de estacionamentos, sujeitando-se, portanto, à tributação sobre a folha de pagamentos. (BRASIL, 2013b).

Lado outro, no que se refere à agroindústria, não há o requisito da exclusividade da atividade, porém, há pressuposto paralelo a ser atendido para fins de enquadramento, com repercussão tributária. Rememore-se que a atividade preponderante da pessoa jurídica agroindustrial é a industrialização da produção rural própria ou a industrialização da produção rural própria e adquirida de terceiros, de sorte que exatamente neste ponto reside o pressuposto.

É que em conformidade com a inteligência do art. 22A da Lei n ${ }^{\circ} 8.212 / 1991$, para enquadrarse a pessoa jurídica como agroindústria é indispensável que a atividade industrializadora recaia parcial ou exclusivamente sobre produção rural própria, impedindo-se que aquela se volte apenas à produção adquirida de terceiros. Na hipótese de inexistência de produção rural própria, a principal consequência consiste na impossibilidade de fruição do regime tributário substitutivo - cobrança do Funrural, em detrimento da contribuição sobre cota patronal -, conforme preconiza o art. 175, parágrafo $2^{\circ}$, inciso II, da IN RFB nº 971/2009 (BRASIL, 2009).

Portanto, sem industrialização de produção rural própria, torna-se inviável a caracterização da pessoa jurídica como agroindústria, o que afasta as regras do Funrural. A respeito disso, observese o seguinte trecho da ementa do acórdão n 2201-004.283, lavrado pelo Carf:

\section{AGROINDÚSTRIA. PRODUÇÃO PRÓPRIA. NECESSIDADE. NÃO DEMONSTRAÇÃO. DESCARACTERIZAÇÃO. \\ Para que a pessoa jurídica possa ser enquadrada como agroindústria e assim usufruir do tratamento tributário favorecido estabelecido para essas empresas pela legislação previdenciária, é necessária a comprovação da condição de produtora rural, bem como da existência de industrialização de matéria prima de produção própria. A aquisição pela empresa de área rural com reflorestamento pronto para abate não é suficiente para caracterizá-la como produtora rural. (BRASIL, 2018c)}

Inclusive, cumpre ressaltar que a existência de produção rural não poderá ser ínfima em comparação com a produção adquirida de terceiros, na medida em que isso impede o enquadramento como agroindústria, igualmente, passando-se a considerar a pessoa jurídica como mera indústria. Extrai-se esse raciocínio dos casos já julgados pelo Carf, atinentes à questão, como no acórdão n ${ }^{\circ}$ 2401-002.263, cujo trecho da ementa está destacado a seguir: 
CONTRIBUIÇÕES PREVIDENCIÁRIAS. A
ENQUADRAMENTO. PRODUÇÃO PRÓPRIA ÍNFIMA.

AGROINDÚSTRIA. NÃO

O regime substitutivo inscrito no artigo $22^{a}$ [sic] da Lei $n^{\circ} 8.212 / 91$, introduzido pela Lei $n^{\circ}$ 10.256/2001, contempla a tributação da Agroindústria, assim considerado o produtor rural pessoa jurídica cuja atividade econômica é a industrialização de produção rural própria ou de produção rural própria e adquirida de terceiros, além de desenvolver suas atividades em um mesmo empreendimento econômico com departamentos, divisões ou setores rural e industrial distinto [sic], não abarcando àquele contribuinte que detém produção própria insignificante se comparada com a adquirida de terceiros, o qual deverá ser considerado como Indústria, hipótese que se vislumbra no caso vertente. (BRASIL, 2012).

Diante do exposto, nota-se que as pessoas jurídicas devem atender aos pressupostos legais e infralegais para viabilizarem a sujeição às regras do Funrural, sendo que, caso não sejam preenchidos os requisitos, será exigida a contribuição previdenciária sobre a folha de salários, predicada no art. 22 da Lei nº 8.212/1991, regra geral de tributação para as pessoas jurídicas de direito privado.

\subsection{A LIBERDADE NEGOCIAL DA INDÚSTRIA E A FRUIÇÃO DO REGIME SUBSTITUTIVO DO FUNRURAL}

Conforme discutido, existem pressupostos de enquadramento da pessoa jurídica como agroindústria, tanto de acordo com o entendimento do Carf, quanto em conformidade com as normas infralegais vigentes. Diante disso, surge outra indagação: é possível que uma indústria seja enquadrada como agroindústria após adquirir propriedade rural, no sentido de beneficiar-se do regime tributário substitutivo do Funrural? Parece-nos que a solução para a questão perpassa por dois pontos: (i) os pressupostos para enquadramento da agroindústria, tratados no tópico anterior; (ii) a liberdade de organização dos negócios, assegurada pelo art. 170 da Constituição de 1988.

No tocante ao primeiro ponto, cumpre repisar que para o enquadramento da pessoa jurídica industrial como agroindústria, não bastará a aquisição da propriedade rural, fazendo-se imprescindível a existência de produção rural própria da empresa, conforme entendimento do Carf.

Por sua vez, entende-se que não há restrições para a realização da operação no sentido de fazer a indústria se tornar agroindústria, na medida em que a liberdade negocial é garantida pelo art. 170, parágrafo único, da Constituição de 1988. Nessa conjuntura, o princípio da liberdade de exercício de atividade econômica garante ao contribuinte a possibilidade de organizar sua atividade, que não poderá ser esvaziada pela intervenção estatal, ainda que o contribuinte vise com isso reduzir sua carga tributária. Isso porque, conforme registra Ávila, “o propósito de economizar está dentro do princípio da liberdade de exercício de atividade econômica” (ÁVILA, 2006, p. 83).

Assim, não se vislumbra qualquer impedimento para que a empresa industrial promova atos no sentido de enquadrar-se como agroindústria, ressalvados sempre os requisitos essenciais para tanto. É plenamente viável que ela se beneficie do regime substitutivo do Funrural e usufrua da 
incidência da contribuição previdenciária sobre a receita bruta proveniente da comercialização da produção rural industrializada, em detrimento da exação que grava a folha de salários.

Por fim e dando um passo adiante, a construção aqui desenvolvida aplica-se integralmente à indústria exportadora, à qual deve ser, inclusive, conferida a imunidade do art. 149, parágrafo $2^{\circ}$, inciso I, da Constituição de 1988, tratada alhures. Nessa perspectiva, a liberdade de organização dos negócios permite que a indústria exportadora se torne agroindústria, ao passo que a teleologia do enunciado normativo imunizante inviabiliza que as receitas auferidas vinculadas à exportação sejam tributadas pelas contribuições sociais.

Por conseguinte, entende-se que o enquadramento da pessoa jurídica como agroindústria é viável desde que preenchidos os requisitos para tanto, de sorte que a partir deste enquadramento a sociedade empresária poderá contribuir para a seguridade social de acordo com as regras do Funrural. Outrossim, não há que se restringir a garantia de livre exercício da atividade econômica dos contribuintes, segundo a qual, neste caso específico, a indústria - exportadora ou não - poderá valerse de rearranjos jurídicos e econômicos, visando determinado regime tributário.

\section{CONSIDERAÇÕES FINAIS}

À guisa de arremate, deve-se retomar as conclusões adotadas em cada um dos tópicos tratados neste estudo. Principiamos com a breve análise do julgamento do RE $n^{\circ}$ 718.874/RS, no qual o STF fixou tese vinculante conferindo constitucionalidade à contribuição do Funrural incidente sobre receita bruta proveniente da comercialização exigida do empregador rural pessoa física, nos termos das modificações da Lei $\mathrm{n}^{0}$ 10.256/2001. Apesar da irresignação de diversos contribuintes com a solução, entende-se que a questão está exaustivamente decidida pelo STF, que detém a última palavra em matéria de interpretação constitucional.

Noutro enfoque, persistem outras controvérsias constitucionais a serem decididas pelo STF, sendo que essa pesquisa tratou de três, sumarizadas a seguir.

A primeira trata do recolhimento sobre a receita bruta pelo segurado especial, o que se entende inviável, sobretudo por se tratar de pessoa física. A segunda controvérsia cuida da exigência de Cofins concomitantemente à contribuição ao Funrural, ante a identidade da base tributável eleita. Consoante exposto, entende-se pela inconstitucionalidade desta exigência, pois existem duas contribuições sociais com mesmo fundamento constitucional e mesma base imponível, caracterizando o bis in idem tributário. A seu turno, a terceira cuida do alcance da imunidade das receitas de exportação no caso dos produtores rurais, pelo que se crê na impossibilidade de tributação 
pelo Funrural nos casos de exportação indireta via trading company ou cooperativa. Nessa linha, há que se atender à teleologia da imunidade, como vem entendendo o STF, que inquestionavelmente visa estimular as exportações, garantindo o superávite da balança comercial e, consequentemente, promovendo a soberania e o desenvolvimento nacional.

Ao final, tratou-se das questões em julgamento e a serem julgadas pelo Carf, pelo que se viu que o enquadramento das pessoas jurídicas como produtoras rurais e agroindústrias possui pressupostos que devem ser adimplidos e repercutem na tributação pelo Funrural. Assim, apenas quando caracterizada como produtor rural e agroindústria poderá a empresa se sujeitar ao regime do Funrural, em detrimento da contribuição previdenciária sobre a folha de salários. Outrossim, para se enquadrar a pessoa jurídica como produtora rural, é essencial o desempenho exclusivo de atividade rural, vedadas as atividades autônomas; lado outro, para o enquadramento como agroindústria é necessário que, além do desempenho preponderante de atividade industrializadora, exista produção rural própria, que não poderá ser ínfima em relação àquela adquirida de terceiros.

Diante dessa conjuntura, compreende-se que apenas as receitas ligadas à atividade agroindustrial e de produção rural poderão ser incluídas na base imponível do Funrural, restando excluídas, à guisa de exemplo, as receitas de ICMS substituição tributária ou de revendas. Por fim, cabe asseverar que as indústrias podem valer-se do regime substitutivo do Funrural, desde que previamente se enquadrem como agroindústrias - atendendo aos pressupostos para tanto -, o que é viabilizado mediante o princípio da liberdade de exercício da atividade econômica.

\section{REFERÊNCIAS}

ÁVILA, Humberto Bergmann. Competências tributárias: um ensaio sobre a sua compatibilidade com as noções de tipo e conceito. São Paulo: Malheiros, 2018.

ÁVILA, Humberto Bergmann. Contribuição do produtor rural pessoa física sobre a receita bruta proveniente da comercialização da sua produção. Subsistência da inconstitucionalidade após a Lei n. 10.256/01. Revista Dialética de Direito Tributário, São Paulo, n. 185, p. 128-141, fev. 2011.

ÁVILA, Humberto Bergmann. Planejamento Tributário. Revista de Direito Tributário, São Paulo, n. 98, p. 74-85, 2006.

BALEEIRO, Aliomar. Limitações constitucionais ao poder de tributar - Comentários de Misabel Derzi à obra de Aliomar Baleeiro. 7. ed. Rio de Janeiro: Forense, 2006.

BRASIL. Congresso Nacional. Constituição da República Federativa do Brasil, de 05 de outubro de 1988. Diário Oficial [da] República Federativa do Brasil, Poder Executivo, Brasília, DF, 05 de outubro de 1988. Seção 1. p. 1. Disponível em: http://bit.ly/2KKXWN1. Acesso em: 11 jan. 2019. 
BRASIL. Conselho Administrativo de Recursos Fiscais. Acórdão 2201-004.283. Processo 13936.000371/2008-48. Valdir Luiz Rossoni e Fazenda Nacional. Relator Dione Jesabel Wasilewski. 6 de março de 2018c. Disponível em: http://idg.carf.fazenda.gov.br/. Acesso em: 11 jan. 2019.

BRASIL. Conselho Administrativo de Recursos Fiscais. Acórdão 2201-004.687. Processo 13116.721914/2014-66. Goiás Verde Alimentos LTDA. e Fazenda Nacional. Relator Rodrigo Monte Loureiro Amorim. 11 de setembro de 2018b. Disponível em: http://idg.carf.fazenda.gov.br/. Acesso em: 11 jan. 2019.

BRASIL. Conselho Administrativo de Recursos Fiscais. Acórdão 2202-003.765. Processo 10935.724226/2014-16. Globoaves São Paulo Agrovícola LTDA. e Fazenda Nacional. Relator Martin da Silva Gesto. 4 de abril de 2018a. Disponível em: http://idg.carf.fazenda.gov.br/. Acesso em: 11 jan. 2019.

BRASIL. Conselho Administrativo de Recursos Fiscais. Acórdão 2401-002.263. Processo 13829.000261/2007-12. Tinto Holding LTDA. e Fazenda Nacional. Relator Rycardo Henrique Magalhães de Oliveira. 7 de fevereiro de 2012. Disponível em: http://idg.carf.fazenda.gov.br/. Acesso em: 11 jan. 2019.

BRASIL. Conselho Administrativo de Recursos Fiscais. Acórdão 2401-002.284. Processo 15504.002710/2009-17. Funchal LTDA. e Fazenda Nacional. Relator Rycardo Henrique Magalhães de Oliveira. 22 de janeiro de 2013b. Disponível em: http://idg.carf.fazenda.gov.br/. Acesso em: 11 jan. 2019.

BRASIL. Exposição de motivos n ${ }^{\circ}$ 00095/2017 MF da Medida Provisória n ${ }^{\circ} 793$ de 29 de set. de 2017. Diário Oficial [da] União, Brasília, DF, $1^{\circ}$ de ago. de 2017. Disponível em: http://bit.ly/2VRxn9S. Acesso em: 11 jan. 2019.

BRASIL. Secretaria da Receita Federal do Brasil. Instrução Normativa RFB número 971, de 13 de novembro de 2009. Diário Oficial [da] União, Brasília, DF, 17 de novembro de 2009, seção, p. 35. Disponível em: http://bit.ly/2DhEhOo. Acesso em: 11 jan. 2019.

BRASIL. Supremo Tribunal Federal. Acórdão. ADC no 1/DF. Requerentes: Presidente da República; Mesa do Senado Federal; Mesa da Câmara dos Deputados. Relator: Min. Moreira Alves. Brasília, DF, $1^{\circ}$ de dezembro de 1992. Diário da Justiça [da] República Federativa do Brasil, Brasília, DF, 16 junho 1995. Disponível em: http://www.stf.jus.br. Acesso em: 11 jan. 2019.

BRASIL. Supremo Tribunal Federal. Acórdão. RE nº 228.321/MG. Recorrente: Parceria Treinamento e Consultoria em qualidade Ltda. Recorrido: INSS. Relator: Min. Carlos Velloso. Brasília, DF, $1^{\circ}$ de outubro de 1998. Diário da Justiça [da] República Federativa do Brasil, Brasília, DF, 30 maio 2003. Disponível em: http://www.stf.jus.br. Acesso em: 11 jan. 2019.

BRASIL. Supremo Tribunal Federal. Acórdão. RE nº 346.084/PR. Recorrente: Divesa Distribuidora Curitibana de Veículos S/A. Recorrido: União. Relator: Min. Ilmar Galvão. Brasília, DF, 09 de nov. de 2005. Diário da Justiça [da] República Federativa do Brasil, Brasília, DF, $1^{\circ}$ set. 2006. Disponível em: http://www.stf.jus.br. Acesso em: 11 jan. 2019. 
BRASIL. Supremo Tribunal Federal. Acórdão. RE nº 363.852/MG. Recorrente: Frigorífico Mataboi S/A. Recorrido: União. Relator: Min. Marco Aurélio. Brasília, DF, 03 de fevereiro de 2010. Diário da Justiça [da] República Federativa do Brasil, Brasília, DF, 23 abril 2010. Disponível em: http://www.stf.jus.br. Acesso em: 11 jan. 2019.

BRASIL. Supremo Tribunal Federal. Acórdão. RE nº 627.815/PR. Recorrente: União. Recorrida: Incepa Revestimentos Cerâmicos Ltda. Relatora: Mina. Rosa Weber. Brasília, DF, 23 de maio de 2013. Diário da Justiça [da] República Federativa do Brasil, Brasília, DF, $1^{\circ}$ out. 2013a. Disponível em: http://www.stf.jus.br. Acesso em: 11 jan. 2019.

CARVALHO, Paulo de Barros. Curso de direito tributário. 13. ed. rev. e atual. São Paulo: Saraiva, 2000.

COÊLHO, Sacha Calmon Navarro. O controle de constitucionalidade das leis e o poder de tributar na CF/1988. 4. ed. Rio de Janeiro: Forense, 2016.

COÊLHO, Sacha Calmon Navarro. Teoria geral do tributo, da interpretação e da exoneração tributária. 4. ed. Belo Horizonte: Fórum, 2018.

COSTA, Regina Helena. Curso de direito tributário: Constituição e Código Tributário Nacional. São Paulo: Saraiva, 2009.

FONSECA, Fernando Daniel de Moura. Imposto sobre a renda: uma proposta de diálogo com a contabilidade. Belo Horizonte: Fórum, 2018.

MACHADO, Schubert de Farias. Conceito Constitucional de Receita. Revista Brasileira de Direito Tributário e Finanças Públicas, Porto Alegre, v. 11, n. 64, p. 91-105, set./out. 2017.

MARTINS, Ives Gandra da Silva. Tributação sobre a receita. Revista Brasileira de Direito Tributário e Finanças Públicas, Porto Alegre, v. 11, n. 64, p. 5-30, set./out. 2017.

André Mendes Moreira Professor Adjunto de Direito Tributário nos Cursos de Graduação, Mestrado e Doutorado da UFMG. Professor Adjunto de Direito Tributário no Curso de Mestrado em Direito Empresarial das Faculdades Milton Campos. Doutor em Direito Econômico e Financeiro pela USP (2009) e Mestre em Direito Tributário pela UFMG (2005), onde também se bacharelou em Direito (2002). Professor convidado nos cursos de especialização em Direito Tributário das Faculdades Milton Campos e do Instituto Brasileiro de Estudos Tributários - IBET. Email: andre@sachacalmon.com.br

Luiz Felipe Mendes Álvares da Silva Campos Graduado em Direito pela UFMG. E-mail: luizfelipemendes@hotmail.com 